\title{
Ambiances
}

anbiances Environnement sensible, architecture et espace urbain Varia | 2014

\section{How does it feel to travel through a tunnel?}

Designing a mundane transit space in Denmark

Que ressentez-vous quand vous traversez un tunnel ? Conception d'un espace de transport ordinaire au Danemark

Ditte Bendix Lanng

\section{OpenEdition}

\section{Journals}

\section{Electronic version}

URL: http://journals.openedition.org/ambiances/454

DOI: 10.4000/ambiances.454

ISSN: 2266-839X

Publisher:

Direction Générale des Patrimoines - DAPA - MCC, UMR 1563 - Ambiances Architectures Urbanités $(\mathrm{AAU})$

Electronic reference

Ditte Bendix Lanng, " How does it feel to travel through a tunnel? », Ambiances [Online], Varia, Online since 15 October 2014, connection on 19 April 2019. URL : http://journals.openedition.org/ ambiances/454; DOI : 10.4000/ambiances.454

This text was automatically generated on 19 April 2019

\section{(9) $\Theta \Theta \Theta$}

Ambiances is licensed under a Creative Commons Attribution-NonCommercial-NoDerivatives 4.0 International License. 


\title{
How does it feel to travel through a tunnel?
}

\author{
Designing a mundane transit space in Denmark \\ Que ressentez-vous quand vous traversez un tunnel? Conception d'un espace de \\ transport ordinaire au Danemark
}

Ditte Bendix Lanng

\section{Introduction: the tunnel}

1 The tunnel (illustration 1) facilitates the crossing between a large road and a bicycle/ pedestrian path. It is located within a suburban district's main local service centre, an infrastructural and functional node connected to a network of roads and paths. The tunnel enables the passage of multiple flows of people, who move through it (illustration 2) - by bike, foot, motor bike, rollerblades, etc. Some travel alone, others two-by-two, and still others in groups. They travel at different times of day, speeds and rhythms - to school, from the bus, along the pathway. The tunnel connects dwellings and local service facilities in its proximity, including a grocery store, public school, cultural center, library, and health care facility (illustration 3). The interior rectangular space of the tunnel is approximately 40 meters long, 6 meters wide, and 3.5 meters high. Walls and ceiling are cast in grey concrete. The floor of the tunnel consists of the path going through it, which is divided in two parts: the asphalt bike path, approximately 3.5 meters wide, and the tiled concrete foot path, approximately 2 meters wide. The two paths are separated by a narrow dirt-and-grass verge. At each end the tunnel meets its surroundings with vertical concrete edges. Small lamps illuminate the tunnel at all times. It appears somewhat derelict with layers of worn graffiti, broken lamps and heaps of trash. 
Illustration 1: The tunnel, Aalborg, Denmark (September 2011)

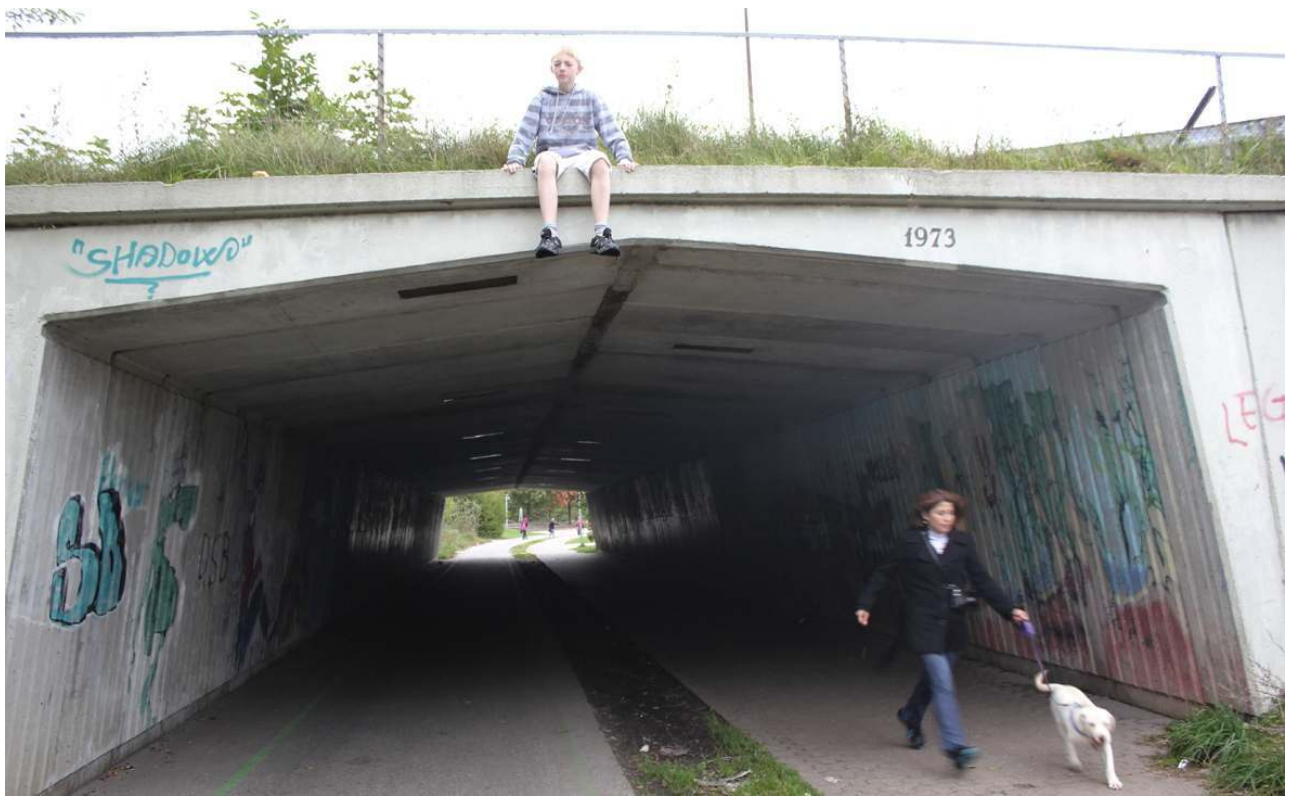

SOURCE AND COPYRIgHT: DITTE BENDIX LANNG

Illustration 2: Flows of people, in and around the tunnel (November 2011)
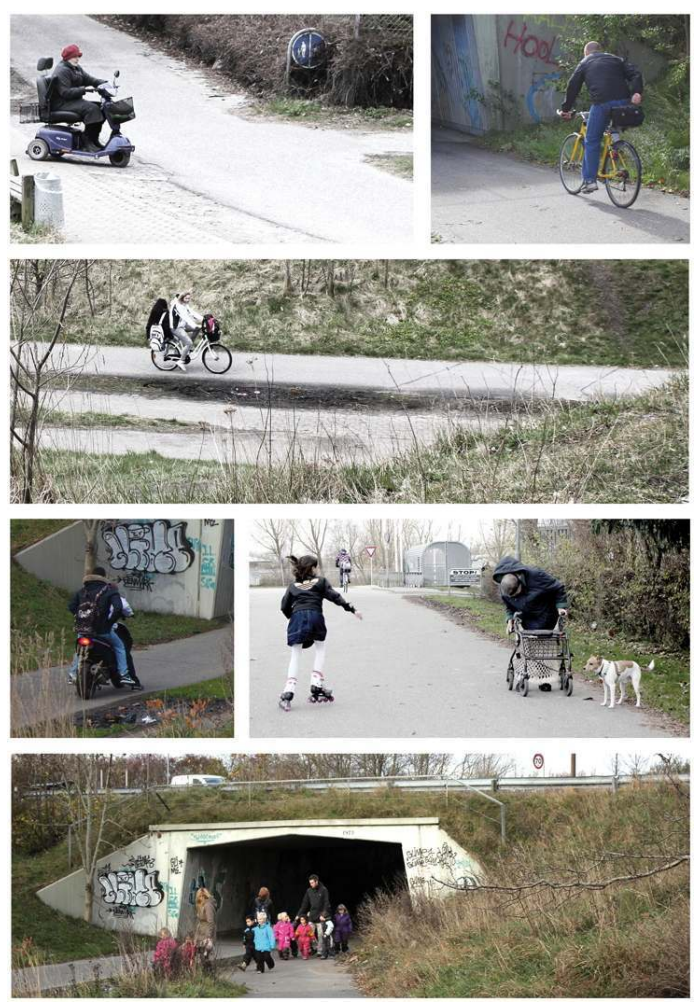

SOURCE AND COPYRIGHT: DITTE BENDIX LANNg 
Illustration 3: Site plan

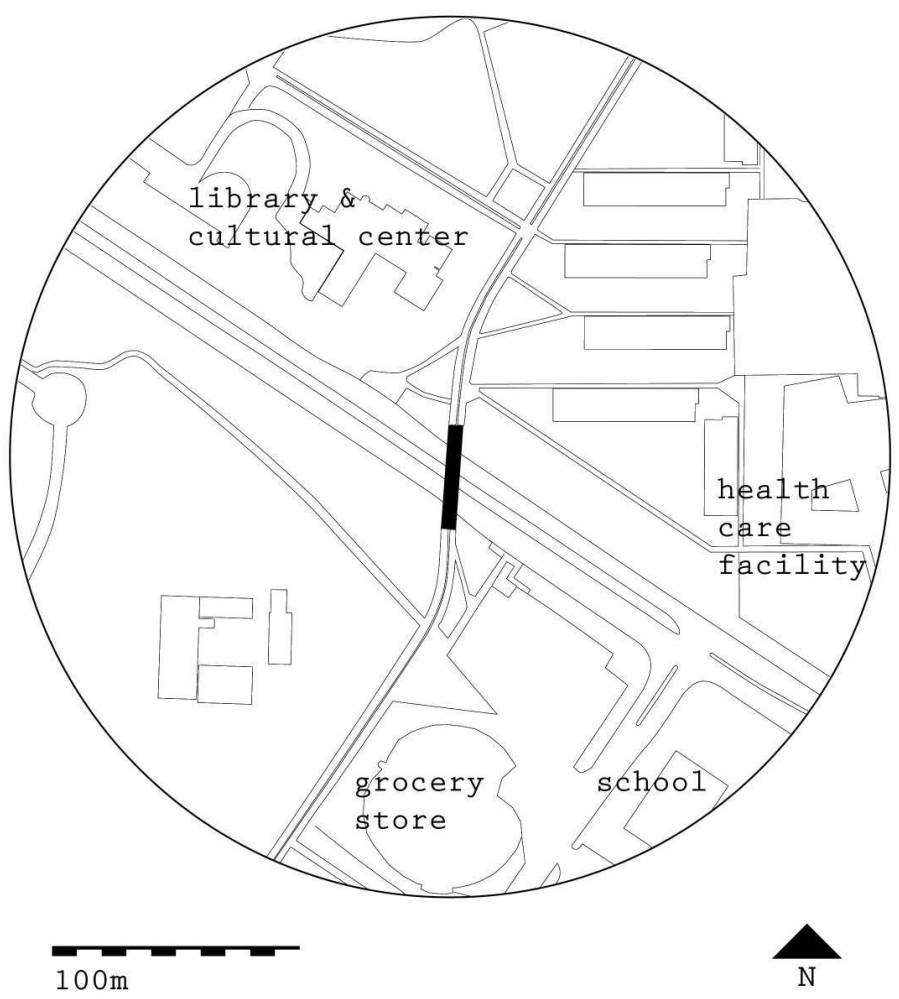

SOURCE AND COPYRIGHT: DITTE BENDIX LANNg

Illustration 4: The interior space of the tunnel (September 2011)

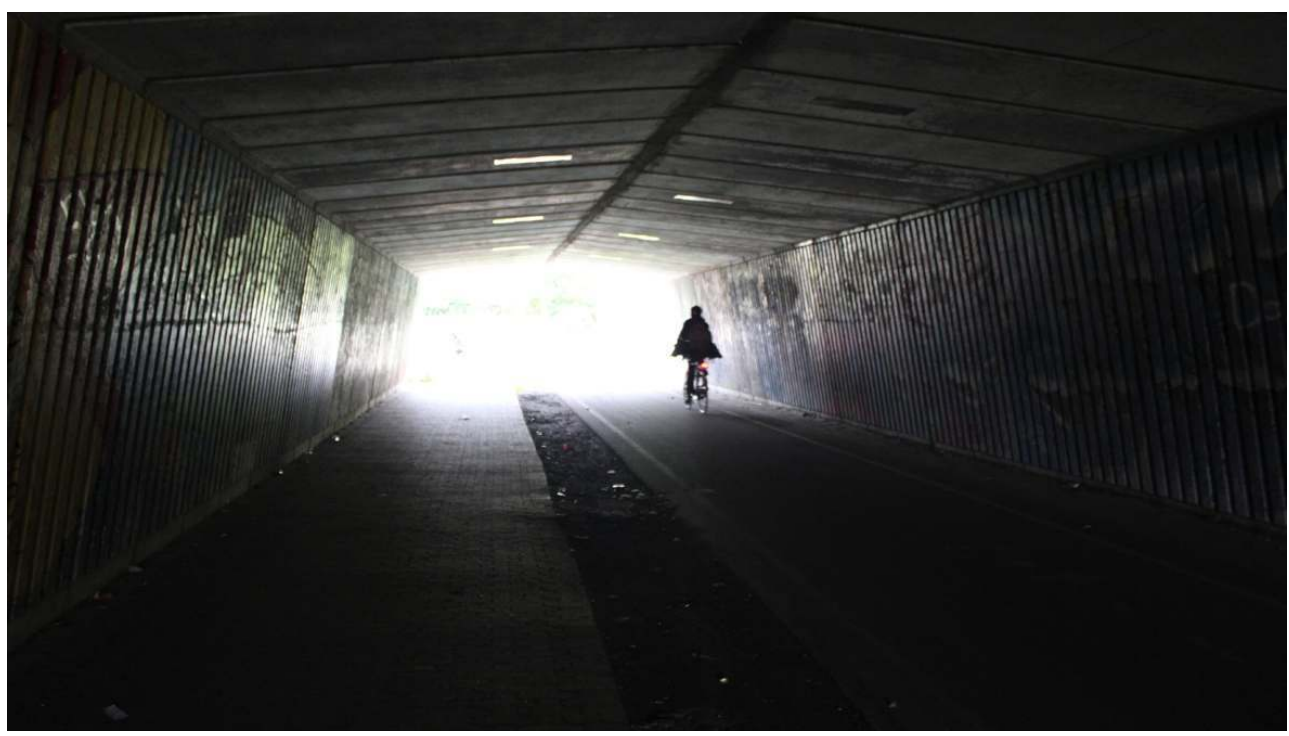

SOURCE AND COPYRIgHT: DITTE BENDIX LANNg

2 Like other tunnels, this tunnel is mainly experienced from within (illustration 4). Upon entering the interior space of a tunnel the effects of weather are neutralised, and a clinical artificial light often supersedes daylight, dusk or the darkness of the outdoors (Hasse, 2012). This may contribute to an "empty and cool spatial atmosphere"; in a tunnel an "aseptic and claustrophobic expression" may be expected (p.154) ${ }^{1}$. The exit from a 
tunnel is also affective; during the day the bright light at the end of the tunnel provides an abrupt transition as one emerges from it, and at night the sense of the open horizon, the skies and the liberty to move more freely constitute a remarkable shift (ibid.). Such atmospheric descriptions might be indicative of many experiences of passing through a tunnel but the case study this paper describes brings forth nuances to our understanding of how it feels to travel through a tunnel and points to an underused potential of designing transit space beyond its utilitarian-only purpose and atmospheres of anxiety.

Following the introduction, the paper outlines the interwoven moments of a critique of the assumed utilitarian-only purpose and a pathway to a constructive vision of the tunnel design. It then takes us into the tunnel to reverberate how it feels to travel through it and to identify material gestures of travelling. The final section of the paper consists of hypothetical architectural explorations that confront the underused design potential for the tunnel to be a sensorial and social public space.

\section{Re-imagining the tunnel: critique and constructive vision}

4 There is a utopian torrent to this paper that relates to a rich stream of scenarios and experiments on mobility and the city, which push our imagination and discussions about visions for the future (Jensen \& Freudendal-Pedersen, 2012). In the study hypothetical redesign operations are conducted on the real situation of the tunnel, channelling through sketches the imagination of alternative architectural possibilities. Thus, design is central. "[T]he designerly capacity" is used "to both project an alternative vision for the future and to direct this projection to present repressed conditions from a critical perspective" (Dyrssen, 2011, p. 233). Hence, there are two interwoven sides of this paper: a "critique", i.e. the critical challenge of established ways of thinking and making material transit space, and a "constructive vision" (Jensen \& Freudendal-Pedersen, 2012, p. 200), i.e. the exploration of fruitful potentials to think and do otherwise.

5 The design development is not a strategy of rational problem-solving but points at design as a research practice, which, in a problem field of uncertainty, aims to open up a pathway for the future of transit space design rather than defining a set target (see Ingold, 2014). Transit space design might be encircled as a non-singular "wicked problem", which must adhere to a plurality of goals and measurements of its success (Rittel \& Webber, 1973). There is no one-best answer to the tunnel design; rather, its resolution is an act of balancing in a field that is context-, situation-, and time-dependent. As such the sketches included in this paper do not display final answers for how to redesign the tunnel; nor is the objective of the research to represent the existing condition of the tunnel. Instead, the paper follows a non-representational and pragmatist animation to imagine and produce better futures (Anderson and Harrison, 2010; Jones 2008; Thrift, 2008; Vannini, 2012 \& forthcoming). It seeks to illuminate the ill-defined topic of potential atmospheric qualities of transit space design, envisage relevant and informed questions for their future, and thus fuel collective knowledge as part of "a shared action space" (Dyrssen, 2011, p. 225).

6 Non-representational research arises from an eclectic landscape of post-modern thinking, including, e.g. Actor-Network Theory, post-phenomenology and pragmatism (Vannini, forthcoming). Through its occupation with relations, embodiment and affects, 
this paper adheres to the diverse non-representational, or "more-than-representational", body of work "that seeks better to cope with our self-evidently more-than-human, morethan-textual, multisensual worlds" (Lorimer, 2005, p. 83). Non-representational research reacts to the assumed impossibility of accurate representations by working to "rupture, unsettle, animate, and reverberate rather than report and represent" (Vannini, forthcoming, unpaginated). It is a shift from the methodological preoccupation with structure and order to a research engagement with a hybrid world through "more action, more imagination, more light, more fun, even" (Thrift, 2008, p. 20). This paper, then, is occupied with elaborating questions of the yet-to-be for transit space design, so as to put forward an agenda of re-thinking and possibly re-making some of our most ubiquitous urban spaces. It does so by attending, first, to mundane journeys as "both thought and unthought" (Adey, 2010, p. 149) - to the embodied practices and experiences, feelings, and atmospheres that come about amidst travellers and the tunnel materialities - and, second, to the ways in which the tunnel architecture co-conditions journey practices and experiences.

\section{Functionalist planning, utilitarian transport and placelessness of transit space}

7 The tunnel was part of the master planning of the district in the mid-20th century. Functionalist principles guided the planning, rooted in the CIAM movement, with the zoned organisation of urban functions as its main principle, dividing transport, dwelling, industry, and recreation (Krieger, 2009). Functionalist transit space design foregrounds safe and efficient traffic flows. This rationale took an extensive form with the 1968 Swedish guidelines of SCAFT (Stadsbyggnad, Chalmers, Arbetsgruppen för Trafiksäkerhet/City building, Chalmers Technical University, working group for traffic safety), suggesting urban planning principles that observed traffic safety. These guidelines, explicating also the road planning principles of Denmark at that time (Harder, 2003), were developed to handle the increasing automobility in urban areas and facilitate traffic flow with a minimum of conflicts and disorder through recommendations such as easy access to welfare community facilities, traffic segregation, and simple and uniform design (Hagson, 2000).

8 The tunnel is a vivid material manifestation of these principles. It provides the intersection between various modes of mobilities, segregating the incongruent movements of smooth, ruled and fast traffic of the insulated "iron cages" (Urry, 2007) and the looser and more vulnerable mobilities of bicyclists and pedestrians. The tunnel interior, though the domain of those slower forms of mobility, follows the universal design code of the SCAFT guidelines. It is kept simple, with a uniform expression to maintain the traveller's concentration on the traffic situation (Hagson, 2000). Yet this design does not consider the embodied experience or the social and spatial engagements that occur on the move. Instead, functionalist car-oriented rationales are "frozen" in generic forms of concrete and asphalt (Urry, 2007). Such design has been heavily criticised for being exclusively (mono-)functional and lacking sensuous and social qualities, orchestrating only a sparse, trivial, and desensitizing transport activity, peoplehostile "dead car-only environments", "locking in" social life to automobility (ibid.).

The way we think about transport is inherent in these points about transit space design. "Transport" is concerned with utilitarian movement from A to B; it is characterized "by 
the dissolution of the intimate bond that [...] couples locomotion and perception" (Ingold, 2007, p. 78). Rather than moving by oneself, "the transported traveller" is a generic passenger who is transited from place to place (ibid; see also Cresswell, 2006; Bissell, 2010). Transport means "to carry across", and assumes that "[n]ot so much bodily movement is involved here, unless you are one of those doing the carrying" (Scheldeman, 2011, p. 129). Aligned with this, the spaces where transport happens tend to be mourned with a "narrative of loss" (Arefi, 1999) associated with the automobility domination, seemingly eliminating the option for meaningful (pre-modern slow) public life (Jacobs, 1961). Such spaces are marked by an abundance of movement, and perhaps therefore assumed to be aseptic "placeless" environments (Cresswell 2006). Indeed, transit spaces might be noted as alienating "non-places" (Augé, 1995) of detachment, lacking cultural and social meaning.

This paper finds it worthwhile to interrogate such conventional understanding of transport and the way we tend to patronize transit space. It does so in line with the rich unpacking of mobilities undertaken in current mobilities studies (e.g. Cresswell, 2006; Urry, 2007; Vannini, 2012; Jensen, 2013), and not least in the emerging field of "mobilities design" (Lanng, Harder \& Jensen, 2012; Jensen, 2014). The proposition is that transit spaces should not be necessarily "placeless" and transport is not, per se, a passive and desensitized practice. There may be many indifferent or alienating experiences related to travelling through transit space, but this is not the only outcome of urban mobilities (Jensen, 2009). This has been shown by, e.g. Vannini in his ethnographic research on ferry travel in West Canada (2012). Vannini contrasts "transport" with "wayfaring": people are not just being transported when they travel by ferry; rather, they are wayfarers who "perform journeys". A journey is a "mundane but meaningfully ritualistic and artful practice which creates occasions for unique interaction settings and relationships" (p. 162). Rich stories, feelings, embodied experiences and interactions are inherent in wayfaring. The ferry wayfarers live lives while on the way, with social, cultural and sensorial complexity.

These points suggest that we should consider transit space design beyond that of the functionalist agenda and allow for social and sensorial agencies to be included in our considerations. This is by no means a new ambition. Adequacy of the functional terminology were being questioned in the 1950s during the initiation of Urban Design that sought to synthesise modernist functional urbanism with concerns for human scale and the collective urban population (Krieger, 2009; Mumford, 2009). Yet when focusing specifically on transit space design it is important to challenge the narrow preconceptions of utilitarian transport and find ways to acknowledge the richness of daily journeys. In design there is a significant "reciprocity between ways of seeing and ways of acting" (Corner, 1999, p. 8); as designers, what we draw is shaped by what we see. En route to an alternative design approach, we need to "see" the tunnel beyond its function as a transport facility. To do so we must seek to learn about that which happens on the ground, in the tunnel, and follow the assertion that:

The truth is that the propositions of art and architecture, to the extent that they carry force, must be grounded in a profound understanding of the lived world. (Ingold, 2011: xi)

Here we will begin to learn about how it feels to travel through the tunnel. We will unpack a few concrete "mobile situations" that occur as two school girls travel home from school, and delve into their "little practices" (Jensen, 2013) of wayfaring. Like 
Vannini opened an understanding of mundane ferry journeys as far more than "A to B", thereby signifying a gap between a narrow transport focus and the richnesses of wayfaring ways of life, the mobile situations explored in this paper show that wayfaring in the tunnel is not necessarily a passive and desensitized practice but that, in fact, social and sensorial engagements take place there.

\section{On the move in the tunnel}

The mobile situations presented in this section are drawn from a film-elicitation study (Murray, 2010; Pink \& Mackley, 2012) of a journey through the tunnel. I joined two school girls on their walk home from school in June 2012, talked to them, video-recorded our journey, and afterwards met again for a follow-up interview during which we watched parts of the video together. This visual ethnographic method aims at the "lived experience" (Degen, Rose \& Basdas, 2010). In its minute attention to individual narratives it seeks to unpack social and sensorial moments that emerge along the way and then aim at some of the more-than-representational registers of travelling that are difficult to capture:

All forms of mobility are profoundly embodied and consequently much of the experience of moving has remained stubbornly beyond the means of the visual and the verbal to decode. (Spinney, 2009, p. 818)

Through this method we can enlarge our understanding of the ways in which the tunnel co-conditions how it feels to travel through it:

[I]t is through paying attention to embodied practices, meaning kinaestheticsensory engagements, that we can start to understand the unstable and complex entanglements configured through the constant re-assemblage of entities and corporeal intensities. (Degen, Rose \& Basdas, 2010, p. 63)

There is a two-fold goal of this in-depth single case study. First, it tests the proposition that mundane transport is actually better understood as wayfaring by "the force of the example" (Flyvbjerg, 2006, p. 228). Second, it aims to understand the role of tunnel materialities in the varied and fluid relations with the girls.

The latter purpose demands some conceptual clarification: how can we understand the relations between wayfarers and the solidity of the tunnel? A point of departure is an Actor-Network Theory perspective on design, assuming that design objects can "trigger" actions (Fallan, 2008; Latour \& Yaneva, 2008; Yaneva, 2009, 2012). We may foreground the term "affordance" and pay close attention to "how design shapes, conditions, facilitates and makes possible everyday life sociality" (Yaneva, 2009, p. 280). Affordance targets how wayfarers are invited to share agency with the materialities of the tunnel. Here I am interested in interrogating the role of architecture in possible situations when the tunnel emerges as a social environment and a "sensory fabric" of such a shared agency (Thibaud, 2011). The tunnel works as a resource for action and embodied affect. It invites, obliges and impedes practices. In a study on mundane situations in urban spaces (such as people waiting on a bench, or looking at shoes in a shop window) this is asserted:

These moments are made possible by specific conjunctions of experiential corporealities and material surroundings. The physicality of the city constantly interacts, supports and collides with our bodies. And our bodies respond, go along with, or ignore these environmental affordances. (Degen, Rose \& Basdas, 2010, p. 60) 
Embodiment, affect and mobilities interconnect in non-quantifiable experiences of materialities, which might be captured by the notion of atmosphere (see e.g. Böhme, 1993). "Affective atmospheres" (Anderson, 2009; Bissell, 2010) emerge on the move as bodily perceived and sensed qualities in the relationship between people and objects. An affective atmosphere might fruitfully be thought of as a "propensity: a pull or a charge that might emerge in a particular space which might (or might not) generate particular events and actions, feelings and emotions" (Bissell, 2010, p. 273). Such atmospheres are difficult to capture, yet ubiquitous and forceful:

Whilst these atmospheres are invisible, nonrepresentational, they form part of the ubiquitous backdrop of everyday life on the move. However, rather than being inert, background or ephemeral phenomena, atmospheres are forceful and affect the ways in which we inhabit these spaces. As such, affective atmospheres are central to everyday conduct whilst on the move since different atmospheres facilitate and restrict particular practices. (ibid. p. 272)

We might think of the atmospheric relationship between wayfarer and tunnel in terms of material "gestures". Gestures are not primarily inscribed in the tunnel but are emerging suggestions for temporary affective engagements:

Activated through people's sensory experiences, by moving through, touching, smelling, tasting, hearing and seeing objects and places [...] Gestures are affective suggestions in space, moments of evocation that are materially performed. (Degen, 2008, p. 48-49)

19 Tunnel materialities, then, perform gestures: in relational and ambiguous ways they suggest atmospheric moments of mundane practices and experiences. I will now follow this point and dive into the daily journey of the two girls.

\section{Mobile situations on the journey home from school}

The two girls, aged 13 and 14 at the time of the study, use the local area around the tunnel in their daily life. It is a key access space for them on their repeated journeys between school, public library, sports facilities, and the local grocery store. The girls are thoroughly familiar with the local area and their account, from which I draw the following points, is clearly not confined to the journey home from school. It is instead a complex composition of multiple practices and experiences. During our shared journey and conversations the two girls expressed that the local area facilitates a rich, varied, and meaningful mundaneity of everyday life and ordinary journeys, encompassing friendships, obligations, joys, difficulties, memories, etc. This meaningful enactment is not confined to special events but happens routinely when the girls and the local area share agency. For them walking home from school is a sense-making, cultural producing activity (cf. Jensen, 2013). Their engagements with places, objects, and other people are varied, sensorial and social. On their afternoon journey home from school they meander slowly and casually and are inclined to stop along the way when something captures their attention. Socialities are not bound to particular places; rather they happen on the move when the girls occasionally come across people they know, and, not least, in the intimate and flexible "mobile withs" (Jensen, 2009) formed by the small travel company of the girls and, occasionally, their friends.

21 Below I describe three situations that stood out during the study of the journey. The situations express some ambiguity about the tunnel gestures, which afford grains of unpleasantness to the girls but also moments of joyful sociality. 

the steep but short slope, a result of vertical traffic segregation, to reach the upper edge of the tunnel. Here they sit down and chat with their friends. Sometimes they eat snacks bought on the way. This place is not designated for breaks; it is simply an excess area inbetween the road and the path. The girls have plenty of more formal opportunities for lingering in the local area but they like this particular place. It invites casual spontaneity and allows them to be high above ground and swing their legs freely. It is a good place for "just sitting", talking, and greeting acquaintances and strangers who pass by. The moments on the grass strip express a situated and personal appropriation of the tunnel materiality that points to the ambiguity of its gestures. The affective atmospheres of the tunnel are not "sealed off" to an aseptic expression and anxious hurry or desensitizing transport (see Anderson, 2009). Though it coercively organises their wayfaring practices and experiences, the girls also show non-conformity to the design's implicit guidelines for mobile behaviour. They are not solely accelerated or stopped by design scripts, getting "shuffled" across space. They are channelled through the tunnel and dispersed on the other side but they also contest this rigidity of the tunnel's functionalist traffic design. Although the formal material design of the tunnel does not suggest this, this treasured moment on their journey reveals the tunnel as a self-programming and selforganising public space. 
Taking a closer look at the gestures of that strip of grass, we might get a hint of the spatial qualities that invite the girls to engage with it. It faces south and is often blessed with afternoon sunshine. It is not pre-programmed with any activities but provides an informal setting for the girls to sit down, appreciate the view of people passing by and be seen themselves, while enjoying the sun with their backs covered. Observations in urban spaces made by Gehl (1996 [1971]) and Whyte (1980) have found these qualities to be important to the flourishing of urban life.

The tunnel is also an excellent place to stop when it rains. It provides the girls with shelter and a place to get caught up in conversation with their friends before they continue in different directions on the other side of the tunnel. The tunnel roof provides a unique material gesture to their journey: an outdoor on-the-way opportunity to linger without getting wet. In this moment, the assemblage of the girls, their journey, other kids, the tunnel, the weather, etc. overflows the associated content of the tunnel as a passage of anxiety or a non-place.

\section{Transit space design: gestures for wayfaring}

These are a few situations afforded by the tunnel gestures. They reverberate some wayfaring practices and experiences as well as the emergence of affective atmospheres. They also show some simple material gestures for wayfaring: the sheltering roof that invites social get-togethers; the strip of grass above the tunnel that invites casual pauses; and the narrow, long, poorly lit tunnel with low visibility that invites acceleration or the choice of another route. I am naturally wary of holding up these moments as examples of tunnel gestures, and transit space design in general. Many other people travel through the tunnel in numerous ways and many other, arguably different, transit spaces exist. However, from these situations we can draw a few learning points that are important to re-envisioning transit space design.

First, the situations bring forth a considerable social and sensorial heterogeneity, which exists in spite of the ordinariness of the journey and the tunnel. This study thereby supports the theoretical end empirical mobilities research referred to above by falsifying the assumption of the transported traveller and pointing to the relevance of the concept of wayfaring. This critique of the instrumentality of the concept of transport suggests that transit spaces might not merely be about getting from A to B. Thus, it opens the imagination of many more heterogeneous situations that could occur in the tunnel when considering the diversity of flows through it. As a space for wayfaring, the tunnel is an ambiguous place of movement, rest, activity, meeting, and experience (see Urry, 2007), which can be conceived of as a place where wayfarers can cultivate the precious gift of travel time and develop meaningful social practices and experiences (Vannini, 2012).

Second, the film-elicitation study unfolds relations between the girls and the solid tunnel materialities. The mobile situations show that the tunnel gestures afford embodied, atmospheric wayfaring in ambiguous ways. As such the study points to an underused potential in the temporal qualities and multiplicity of the seemingly dull tunnel architecture, highlighting that "[m]atter is much more variable, unpredictable and surprising than expected" (Yaneva, 2012, p. 19). Following these two learning points, the design of transit space should be more than a technical concern of organising inert matter to facilitate flow. We should regard its potential for offering material gestures to a richness of wayfaring practices and experiences. In the next section this way of thinking 
is explored in a fictional design study that targets the material conditions for affective atmospheres to emerge in the relationship between wayfarers and the tunnel.

\section{Re-designing the tunnel}

31 This section concerns the possible re-articulation of the engagement between wayfarers and transit space design. This is where the design re-imagination, with its utopian traits, can benefit our pursuit of a constructive vision for transit space design, allowing us to explore alternative tunnel materialities and stage these by sketches and tangible questions for the architectural qualities of transit space. First, I outline the method of the design study. Second, I pose four questions about potential re-design operations of the tunnel that explore other possible gestures of mobile situations.

\section{"Architectural thinking-making-composing" - a method for constructive vision}

32 The study has been conducted in an active, explorative and spiraling process of "architectural thinking-making-composing" - a complex of associative, intuitive and logical action and thinking (Dyrssen, 2011). Through design actions it explores an example of how social and sensorial considerations could be included in the tunnel design. This process capitalises on an ongoing reflective oscillation between theory and practice that places "the making at the centre, not as an object for theoretical processing or verification, but as an investigative, creative and compositional practice that may be put at interplay with several theoretical frameworks, specific concepts and experimenting activity" (p. 227). In this process "[a]nalysis is accomplished through action, by staging, provoking or changing the situation" (ibid.). Handling such a process demands "a developed sense of intuitive accuracy" of the "researcher-artist-designer" to navigate and identify strategic points in the open system of the "research assemblage" (p. 228). Dyrssen argues that such skills are key to any research practice. In particular, the researcher-artist-designer should be trained to linger "in the complex and 'fuzzy' state of exploration and uncertainty but at the same time make a situation respond and drive discovery forward as strongly as possible" (p. 229).

The study is formulated as four concrete design questions and operations that explore the underused potential of transit space design. Together they strive to articulate a pathway for the yet-to-be of transit space design, composing a "precise yet opening inquir[y] that can expose something qualitatively new about the situation" while maintaining to "avoid the pitfalls of prematurely seeking final answers" (Dyrssen, 2011, p. 229). The design operations are thus explorative craftings of the connections between wayfarers and the tunnel materialities. They are "not just a way to render objects exotic, desirable or pleasurable" (Yaneva, 2009, p. 282); rather, they experiment with

a way of producing additional attachments that make a variety of actors congregate, forming different groupings and assembling social diversity. [...] design connects us differently, linking disparate heterogeneous elements and effects, thus entering a game of producing, adjusting and enacting the social. (ibid.)

As a modelling strategy the tunnel is torn apart in four design variables: dimensions, materials, edges, and lights. Each of the variables has been isolated analytically to form operational sub-parts that make it possible to work in detail with tunnel gestures, to 
define specific questions for the integration of sensorial and social dimensions, and to explore the potential for other affective atmospheres to occur. The four variables are "strategic agents" (Dyrssen, 2011, p. 235) that stage that the way it feels to travel through a tunnel may be adjusted through re-modelling the tunnel gestures. Through targeting the initial material conditions for the emergence of affective atmosphere, the design operations centre attention on some of the changes we could make to the asphalt and concrete of the tunnel. They have been formulated in a way that superimposes the assumed triviality of the tunnel space with a touch of poetic thinking, to extend the fuzzy and uncertain state of opportunities beyond the designer's studio, and to promote the rethinking, questioning and possible discovery of other options for the future of the tunnel. Many other simulations of alternatives could be made; for now, however, we will concentrate on this single design study that condenses the re-imagination of transit space design.

\section{Hypothetical architectural explorations of wayfaring gestures}

The overall question that the design operations ask is: how could the tunnel with its material gestures for action and affect compel and rearticulate wayfaring ways of life social ties and journey experiences?

The design operations target the future of the tunnel design. In particular, they unfold a careful caress for the body moving through the atmospheric enclosed space. They consider materials, edges, lights, and spatial dimensions of the tunnel that have the capacity to afford tactile and rich experiences and invite wayfarers to use and approximate the tunnel for their own situated journeys and other activities.

Tunnel dimensions (illustration 5): Could we imagine a body-space proportional caress, and daylight reaching far into the tunnel interior, inviting our passage - slow by foot or faster by bike?

This study concerns the embodied sensation of wayfaring in a space of certain perceived proportions: long, short, narrow, wide, high, or low space. In the mobile situations above we saw how the tunnel as a long roofed, enveloped interior provides gestures for both moments of anxiety and joyful pauses. The sketches interrogate the gestures of dimensions by suggesting that the designer sustains the shelter quality but cuts the tunnel length as much as possible and opens its middle area to the sky, allowing daylight to enter its darkest centre and provide a break along the length of the tunnel. 
Illustration 5: Tunnel dimensions, architectural explorations

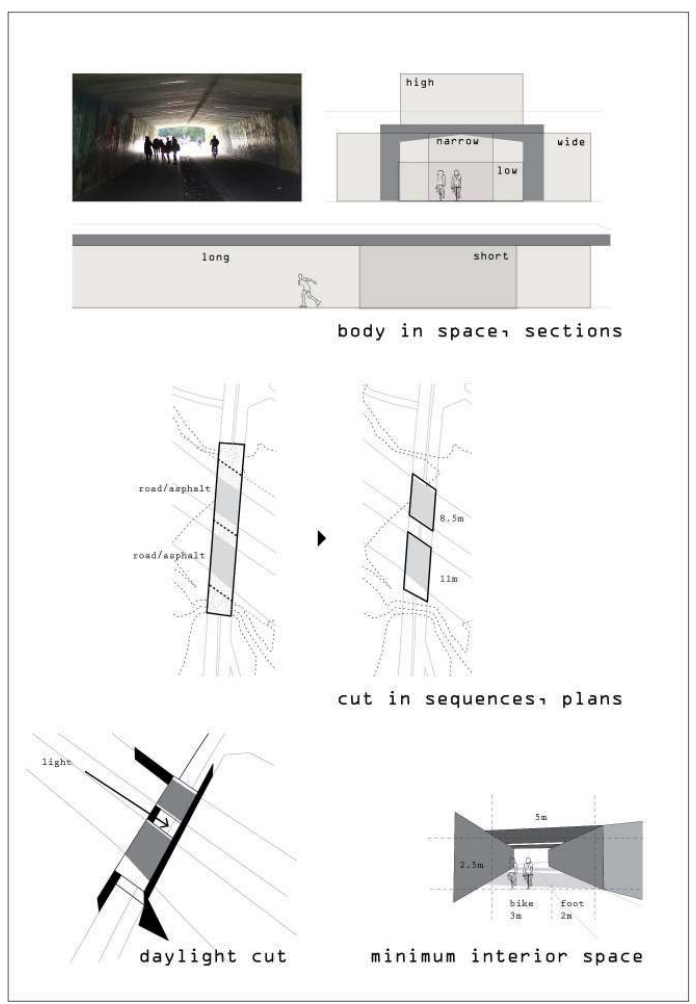

COULD WE IMAgINE A BODY-SPACE PROPORTIONAL CARESS, AND DAYLIgHT REACHINg FAR INTO THE TUNNEL INTERIOR, INVITING OUR PASSAgE - SLOW BY FOOT OR FASTER BY BIKE?

SOURCE AND COPYRIGHT: DITTE BENDIX LANNg

Tunnel materials (illustration 6): Could we imagine some smoothness and warmth to the tunnel interior, some inclination to its wall inviting us to lean upon it and pause in conversation during an in-the-tunnel encounter?

This study concerns the tactile quality of materials: shape, texture and colour. The tunnel is the narrow passage along extensive movement trajectories and in-between large open spaces of the 'thin' suburban district. It is a distinct interface between the wayfarer and the material environment, the only moment at which one is enveloped and able to touch wall materials. The sketches thus interrogate and suggest a material generosity in the tunnel, underlining the contrast to the exterior with carefully twisted wooden lamellas, adding warmth and inclining walls to the architectural resource for action and sensation. 
Illustration 6: Tunnel materials, architectural explorations

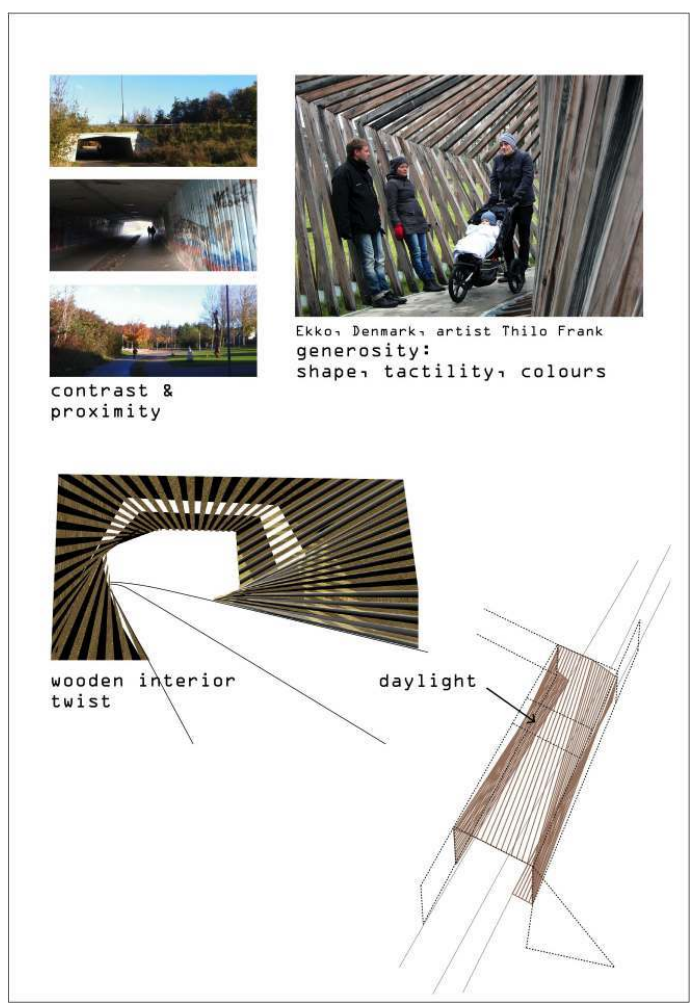

COULD WE IMAgINE SOME SMOOTHNESS AND WARMTH TO THE TUNNEL INTERIOR, SOME INCLINATION TO ITS WALL INVITING US TO LEAN UPON IT AND PAUSE IN CONVERSATION DURING AN IN-THE-TUNNEL ENCOUNTER?

SOURCE AND COPYRIgHT: DITTE BENDIX LANNG

41 Tunnel edges (illustration 7): Could we imagine knitting the tunnel closely with the surrounding urban fabric, some soft and smooth transitions, inviting both entries and exits during continuous journeys?

42 This study concerns the continuity between the tunnel and the surrounding city fabric. Its edges are links between the interior and exterior; they act as both entries and exits to the wayfarers. As such the edges should hold numerous gestures: inviting entries, facilitating welcoming transitions between the surroundings and the tunnel passage, and inviting exits of clear visibility. In addition, and following the analysis above, the south facing edge has great potential as a gesture for casual moments of rest. 
Illustration 7: Tunnel edges, architectural explorations

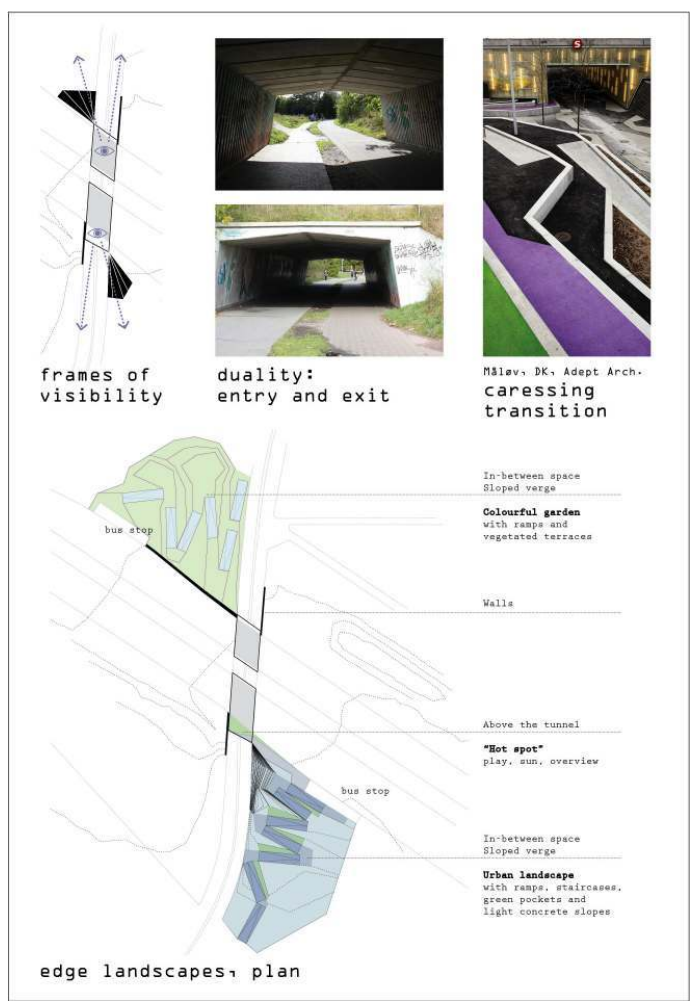

COULD WE IMAgINE KNITTINg THE TUNNEL CLOSELY WITH THE SURROUNDING URBAN FABRIC, SOME SOFT AND SMOOTH TRANSITIONS, INVITING BOTH ENTRIES AND EXITS DURING CONTINUOUS JOURNEYS? SOURCE AND COPYRIgHT: DITTE BENDIX LANNg

Tunnel lights (illustration 8): Could we imagine weaving the interior intimate passage with the open space paths on either side - some lit continuity, inviting night-time journeys?

This study is primarily concerned with the continuous and safe experience of travelling through the tunnel by night. In addition, it looks at how daylight "filters" (Thibaud, 2011) into the tunnel through the wooden lamellas described above. With regard to night-time lighting the sketches focus on two gestures: a continuous light system, facilitating a smooth and well-lit transition between the exterior large open spaces and the interior passage, and a careful caress of the lighting of the intimate tunnel space itself: soft effect lights integrated in the lamellas, underlining the shape and the direction. 


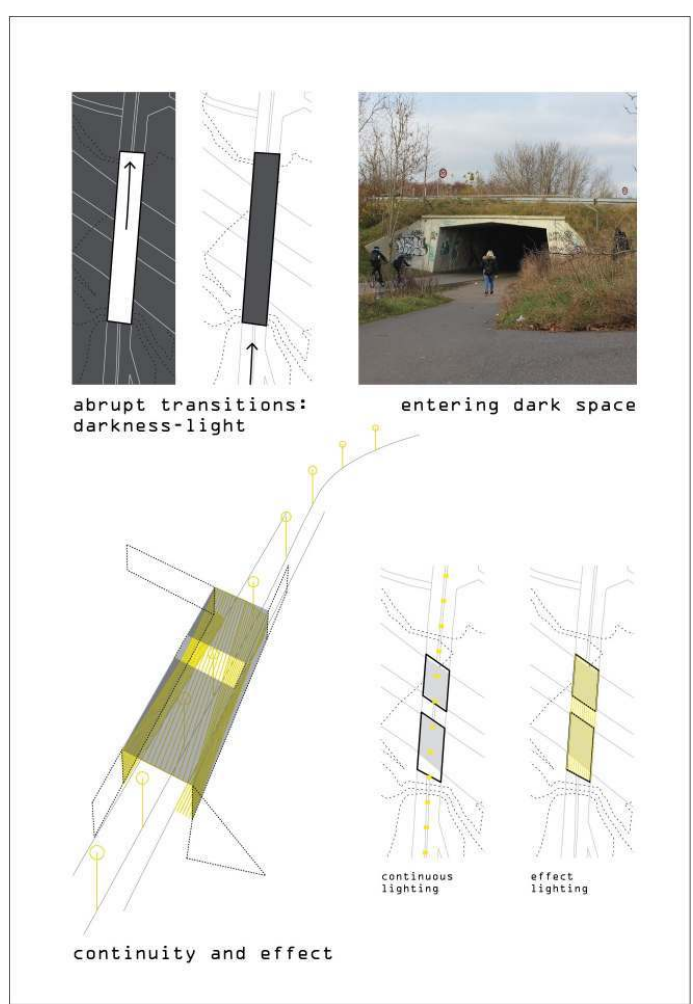

COULD WE IMAgINE WEAVING THE INTERIOR INTIMATE PASSAgE WITH THE OPEN SPACE PATHS ON EITHER SIDE - SOME LIT CONTINUITY, INVITING NIGHT-TIME JOURNEYS?

SOURCE AND COPYRIgHT: DITTE BENDIX LANNg

This design study into the gestures of the tunnel points at architectural possibilities for mediating enjoyable and meaningful journeys and inviting wayfarers to engage in urban life and meet others. The optic and tactile have been the focus, but more design potential awaits, e.g. sound and smell should be employed when exploring further the multisensory encounter between the tunnel and wayfarers. As such the four architectural explorations provide only a simple starting point for the yet-to-be of transit space design. They exemplify the possibility of generating alternatives for further action, thus staging transit space design as an open action field of potentials, in which we have the opportunity to adjust the material gestures for wayfaring.

\section{Conclusion}

When (re-)designing the transit spaces of the future we should ask ourselves how it feels to travel through them. This paper suggests the relevance of re-envisioning transit space design beyond its utilitarian-only purpose and formulating questions for the future that develop from a reflective understanding of embodied wayfaring.

First, the paper outlines a critique of the assumed utilitarian-only purpose and placelessness of transit space. Functionalist transit space design focuses on facilitating instrumental transport, but the paper shows that there is a gap between this narrow transport focus and the rich practices and experiences of wayfaring. Through reference to empirical and theoretical mobilities research, and through reverberating concrete 
embodied situations of wayfaring, the paper elaborates the question of how it feels to travel through some of our most ubiquitous and utilised public spaces. Further, the study into the journey home from school shows that we can think of the tunnel as providing the initial material gestures for our embodied practices and experiences - as affording affective suggestions for wayfarers to temporarily engage with it and each other along their way. The film-elicitation of the situated journey initiates a methodological way to animate the more-than-representational registers of ordinary wayfaring in transit spaces. Its strength is the detailed unpacking of the hard-to-grasp relational engagements and affective atmospheres that emerge between wayfarers and transit space materialities, whereas, in this form, it does not consider the diversity of users. For future research, more effort could be directed towards following different wayfarers and the creation of multiple atmospheric relationships in transit spaces, thereby explicating more of the many wayfaring ways of life and the material gestures that invite them. For now, however, the narrow case study lets us see that the lived experience of transit space can be variable and rich, and that simple material gestures invite various wayfaring ways of life.

Second, and following this, the paper proposes that the yet-to-be of transit space design should supplement the functional design agenda with considerations of embodiment, practices and atmosphere. Through four hypothetical architectural explorations the paper confronts the existing situation in the tunnel and stages a series of tangible, yet imaginative, questions to the material changes we could do. Rather than suggesting an end-point for the design of the tunnel, this method strives to feed a shared open action space of transit space design with a simple starting point, by extending the fuzzy and uncertain state of opportunities beyond the designer's studio, and delve into the possibility for designing gestures of transit space to include a detailed sensitivity to the interrelations between wayfarers and materialities. As such it is used to stimulate the imagination of change, of the underused potential of transit space design to enlarge architectural resources for action and affect - for social and sensorial wayfaring.

\section{Acknowledgements}

This paper is part of the author's Ph.D. research within the project "Aalborg Øst - en forstad i forandring" at Aalborg University's Department of Architecture \& Media Technology. The project is headed by associate professor Henrik Harder and co-financed by Fonden Realdania and local housing organisations. The research presented in this paper has benefited from activities in the university's Urban Design Research Group and Center for Mobilities and Urban Studies (c-mus.aau.dk) and, in particular, from the Mobilities Design Group, where professor Ole B. Jensen's devoted engagement keeps pushing research into "mobilities design". 


\section{BIBLIOGRAPHY}

\section{Bibliography}

Adey, Peter. 2010. Mobility. Abingdon: Routledge. 267 pages.

Anderson, Ben. 2009. Affective Atmospheres. Emotion, Space and Society. vol. 2, n² 2, p. 77-81.

Anderson, Ben \& Harrison, Paul. 2010. The Promise of Non-Representational Theories. In: Anderson, Ben \& Harrison, Paul (eds.). Taking Place: Non-Representational Theories and Geography. Burlington: Ashgate. p. 1-34.

Arefi, Mahyar. 1999. Non-place and Placelessness as Narratives of Loss: Rethinking the Notion of Place. Journal of Urban Design. vol. 4, n 2, p. 179-193.

Augé, Marc. 1995. Non-places: An Introduction to Supermodernity. London: Verso. 122 pages.

Bissell, David. 2010. Passenger Mobilities: Affective Atmospheres and the Sociality of Public Transport. Environment and Planning D. vol. 28, $n^{\circ} 2$, p. 270-289.

Böhme, Gernot. 1993. Atmosphere as the Fundamental Concept of a New Aesthetics. Thesis Eleven. 36, p. 113-126.

Corner, James. 1999. Introduction: Recovering Landscape as a Critical Cultural Practice. In: Corner, James (ed.). Recovering Landscape. New York: Princeton Architectural Press. p. 1-28.

Cresswell, Tim. 2006. On the Move - Mobility in the Modern Western World. New York: Routledge. 327 pages.

Degen, Monica. 2008. Sensing Cities. New York: Routledge. 225 pages.

Degen, Monica, Rose, Gillian \& Basdas, Begum. 2010. Bodies and Everyday Practices in Designed Urban Environments. Science Studies. vol. 23, n 2, p. 60-76.

Dyrssen, Catarina. 2011. Navigating in Heterogeneity: Architectural Thinking and Art-based Research. In: Biggs, Michael \& Karlsson, Henrik (eds.). The Routledge Companion to Research in the Arts. New York: Routledge. p. 223-239.

Fallan, Kjetil. 2008. Architecture in Action: Traveling with Actor-Network Theory in the Land of Architectural Research. Architectural Theory Review. vol. 13, n 1, p. 80-96.

Flyvbjerg, Bent. 2006. Five Misunderstandings About Case-Study Research. Qualitative Inquiry. vol. $12, \mathrm{n}^{\circ} 2$, p. 219-245.

Gehl, Jan. 1996 [1971]. Livet mellem husene. København: Arkitektens Forlag. 192 pages.

Hagson, Anders. 2000. Stads- och trafikplaneringens paradigm. Göteborg: Chalmers Tekniska Högskola. 233 pages.

Harder, Henrik. 2003. A "Network" and a "Dictum". Proceedings of the AESO ACP Third join Congresse, Leuven 2003.

Hasse, Jürgen. 2012. Atmosphären der Stadt. Aufgespürte Räume. Berlin: Jovis Verlag. 192 pages. Ingold, Tim. 2007. Lines: A Brief History. London: Routledge. 186 pages. 
Ingold, Tim. 2011. Being Alive. Essays on Movement, Knowledge and Description. New York: Routledge. 288 pages.

Ingold, Tim. 2014. Designing Environments for Life. In: Hastrup, Kirsten (ed.). Anthropology and Nature. New York: Routledge. p. 233-246.

Jacobs, Jane. 1961. The Death and Life of Great American Cities. New York: Random House. 458 pages. Jensen, Ole B. 2009. Flows of Meaning, Cultures of Movement - Urban Mobility as Meaningful Everyday Life Practice. Mobilities. vol. 4, n 1, p. 139-158.

Jensen, Ole B. 2013. Staging Mobilities. London: Routledge. 228 pages.

Jensen, Ole B. 2014. Designing Mobilities. Aalborg: Aalborg Unversity Press. 297 pages.

Jensen, Ole B. \& Freudendal-Pedersen, Malene. 2012. Utopias of Mobilities. In: Jacobsen, Michael Hviid \& Tester, Keith (eds.). Utopia: Social Theory and the Future. Aldershot: Ashgate. p. 197-218.

Jones, Owain. 2008. Stepping from the Wreckage: Geography, Pragmatism and Antirepresentational Theory. Geoforum. vol. 39, $n^{\circ}$ 4, p. 1600-1612.

Krieger, Alex. 2009. Introduction: An Urban Frame of Mind. In: Krieger, Alex \& Saunders, William S. (eds.). Urban Design. Minneapolis: University of Minnesota Press. p. vii-xix.

Lanng, Ditte B.; Harder, Henrik \& Jensen, Ole B. 2012. Towards urban mobility designs: en route in the functional city. Selected Proceedings from the Annual Transport Conference at Aalborg University. Available: http://vbn.aau.dk/files/66798055/Towards_Mobility_Designs.pdf (accessed 2014 july 5th)

Latour, Bruno \& Yaneva, Albena. 2008. "Give Me a Gun and I Will Make Buildings Move”: An ANT 's view of Architecture. In: Geiser, Reto (ed.). Explorations in Architecture: Teaching, Design, Research. Basel: Birkhäuser. p. 80-89.

Lorimer, Hayden. 2005. Cultural Geography: the Busyness of Being 'More-than-representational'. Progress in Human Geography. vol. 29, n 1, p. 83-94.

Mumford, Eric. 2009. The Emergence of Urban Design in the Breakup of CIAM. In: Krieger, Alex \& Saunders, William S. (eds.). Urban Design. Minneapolis: University of Minnesota Press. p. 15-38.

Murray, Lesley. 2010. Contextualising and Mobilising Research. In: Fincham, Ben; McGuinness, Mark \& Murray, Lesley (eds.). Mobile Methodologies. Basingstoke: Palgrave Macmillan. p. 13-24.

Pink, Sarah \& Mackley, Kerstin L. 2012. Video and a Sense of the Invisible: Approaching Domestic Energy Consumption through the Sensory Home. Sociological Research Online. vol. 17, $\mathrm{n}^{\circ} 1$ [on line]. Available: http://www.socresonline.org.uk/17/1/3.html (accessed 2014 july 5th).

Rittel, Horst W. \& Webber, Melvin M. 1973. Dilemmas in a General Theory of Planning. Policy Sciences. $\mathrm{n}^{\circ} 4$, p. 155-169.

Scheldeman, Grit. 2011. Beyond A to B. In: Ingold, Tim (ed.). Redrawing Anthropology: Materials, Movements, Lines. Aldershot: Ashgate. p. 129-141.

Spinney, Justin. 2009. Cycling the City: Movement, Meaning and Method. Geography Compass. vol. $3, n^{\circ} 2$, p. 817-835.

Thibaud, Jean-Paul. 2001. Frames of Visibility in Public Places. Places. vol. 14, n 1, p. 42-47.

Thibaud, Jean-Paul. 2011. The Sensory Fabric of Urban Ambiances. Senses \& Society. vol. 6, n 2, p. 203-215. 
Thrift, Nigel. 2008. Non-representational Theory. Space, Politics, Affect. New York: Routledge. 325 pages.

Urry, John. 2007. Mobilities. Oxford: Polity Press. 336 pages.

Vannini, Philip. 2012. Ferry Tales. New York: Routledge. 264 pages.

Vannini, Philip. Forthcoming. Non-representational Research Methodologies: An Introduction. In: Philip Vannini (ed.). Non-representational Methodologies: Re-envisioning Research. New York: Routledge. Pre-published version at: www.academia.edu/5217885/ Nonrepresentational_Theory_and_Methodologies_Re-envisioning_Research (accessed 2014 july 5th).

Whyte, William H. 1980. The Social Life of Small Urban Spaces. New York: Project for Public Spaces. 125 pages.

Yaneva, Albena. 2009. Border crossings. Making the Social Hold: Towards an Actor-Network Theory of Design. Design and Culture. vol. 3, n 1, p. 273-288.

Yaneva, Albena. 2012. Mapping Controversies in Architecture. Aldershot: Ashgate. 128 pages.

\section{NOTES}

1. Translated by the author from "leeren und kahlen Raumatmosphäre" and "aseptischen und klaustrophobischen Eindruck".

\section{ABSTRACTS}

This paper opens a pathway for a constructive vision of atmospheric qualities of transit space design. It focuses on an ordinary tunnel for pedestrians and cyclists in a suburban district of Aalborg, Denmark. By way of functionalist design and traffic segregation the tunnel facilitates the passage of daily life journeys. Through unpacking concrete mobile situations that occur on a journey home from school and through speculative architectural explorations into a possible redesign of the tunnel, an underused potential is identified for transit space to be a sensorial and social public space. One way of approaching this potential, it is argued, is to work with transit spaces as atmospheric spaces of wayfaring, drawing to the forefront of design considerations the affective engagement between travellers and the material environment. Inherent in this proposition is a critique of the assumptions that daily life travelling can be reduced to a desensitized and passive transport practice and that transit spaces are placeless.

Le présent article ouvre la voie à une vision constructive des qualités d'ambiances dans la conception d'un espace de passage. Il a pour objet un tunnel ordinaire pour piétons et cyclistes dans une banlieue de la ville d'Aalborg, au Danemark. À travers sa conception fonctionnaliste et la séparation des modes de circulation, ce tunnel facilite les déplacements quotidiens. En examinant les situations et les mouvements concrets qui surviennent sur le trajet de l'école au domicile, et au moyen d'explorations architecturales spéculatives dans l'hypothèse d'une possible réhabilitation du tunnel, le potentiel sous-utilisé de cet espace de passage comme espace 
public social et sensible est mis en évidence. Une manière d'appréhender ce potentiel, comme nous le montrons, serait de traiter les espaces de passage comme des espaces d'ambiances pour les déplacements, en mettant en avant, dans la conception, l'engagement affectif entre les voyageurs et l'environnement matériel. Cette proposition implique une critique de l'hypothèse selon laquelle les déplacements de la vie quotidienne peuvent se réduire à des pratiques de transport désensibilisées et passives et que les espaces de passage sont des non-espaces.

INDEX

Mots-clés: espace de passage, conception de la mobilité, design urbain, atmosphère, déplacements

Keywords: transit space, mobilities design, urban design, atmosphere, wayfaring 